\title{
REPOSITORY RELEVANT TESTING APPLIED \\ TO THE YUCCA MOUNTAIN PROJECT ${ }^{\star}$
}

\author{
John K. Bates, Alan B. Woodl and, David J. Wronkiewicz, fin 2 I figh \\ and James $C$. Cunnane \\ Chemical Technology Division \\ ARGONNE NATIONAL LABORATORY \\ 9700 South Cass Avenue \\ Argonne, IL 60439-4837

\section{OSTI}

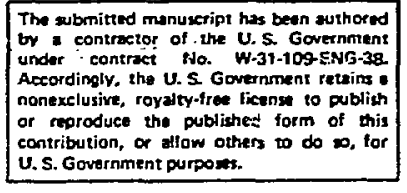

Subritted to

The Journal of the American Ceramics Society
October 1990

*Work supported by the U.S. Department of Energy, Office of Civilian Radioactive Waste Management, Yucca Mountain Project under subcortract to Lawrence Livermore National Laboratory, SANL 910-005 and SANL 910-007. 


\section{REPOSITORY-RELEVANT TESTING APPLIED TO THE YUCCA MOUNTAIN PROJECT}

J. K. Bates, Alan B. Woodland, David J. Wronkiewicz, and James $C$. Cunnane

\section{INTRODUCTION}

The tuff beds of Yucca Mountain, Nevada, are currently being investigated as a site for the disposal of high-level nuclear waste in an underground repository. If this site is found suitable, the repository would be located in the unsaturated zone above the water table, and a description of the site and the methodology of assessing the performance of the repository are described in the Site Characterization Plan (SCP). 1 While many factors are accounted for during performance assessment, an important input parameter is the degradation behavior of the waste forms, which may be either spent fuel or reprocessed waste contained in a borosilicate glass matrix.

To develop the necessary waste form degradation input, the waste package environment needs to be identified. This environment will change as the waste decays and also is a function of the repository design which has not yet been finalized. At the present time, an exact description of the waste package environment is not available. The SCP does provide an initial description of conditions that can be used to guide waste form evaluation. However, considerable uncertainty exists concerning the conditions under which waste form degradation and radionuclide release inay occur after the waste package containment barriers are finally breached. 
The release conditions that are considered to be plausible 2,3 include (1) a "bathtub" condition in which the waste becomes fully or partially submerged in water that enters the breached container and accumulates to fill the container up to the level of the breach opening, (2) a "wet drip" or "trickle through" condition in which the waste form is exposed to dripping water that enters through the top and exits the bottom of a container with multiple holes, and (3) a "dry" condition in which the waste form is exposed to a humid air environment. Performance assessment calculations assume $^{3}$ that the needed waste form degradation rate input for these release conditions is bounded by leaching data. This assumption needs to be checked by conducting tests of waste form performance under conditions that simulate the plausible release conditions identified above. However, the diversity of conditions and the number of interactions and experimental factors involved pose a challenge to developing a suitable testing program. A starting point is to conduct laboratory screening tests which simulate the conditions and configurations in which water is expected to contact the waste. The results can be used to identify whether any potential wastewater contact modes are particularly deleterious to the waste form performance, and whether any interactions between materials present in the waste package environment need to be accounted for when modeling the waste form reaction.

The Unsaturated Test method is one approach that has been developed by the Yucca Mountain Project (YMP) to investigate the above issues for the wet drip release conditions. A description of results that have been obtained during the testing of glass and unirradiated $\mathrm{UO}_{2}$, using the Unsaturated Test method, is the subject of this paper. 


\section{EXPERIMENTAL}

The apparatus used in the Unsaturated Test as applied to glass testing 4 has been described previously. A schematic diagram of a similar system used in the $\mathrm{UO}_{2}$ experiments is shown in Fig. 1 . For both waste forms, the components of the apparatus are the test vesse1, which provides for collection and containment of liquid and support of the waste form; the waste package assemblage (WPA), which consists of the waste form and perforated, presensitized, metallic components representing the pour canister (glass), or zircaloy tubing and support ring $\left(\mathrm{UO}_{2}\right)$; and a solution feed system to inject test water. The $\mathrm{UO}_{2}$ apparatus incorporates a TeflonTM stand to support the $\mathrm{UO}_{2}$ and zircaloy tube. The test is performed at $90^{\circ} \mathrm{C}$.

The WPA is contacted intermittently by small, measured amounts (drops) of :epository water (EJ-13) that has been preequilibrated with tuff at $90^{\circ} \mathrm{C}$. The nature and degree of radionuclide release from the WPA are determined by collection and analysis of the solution and the WPA components. Materials interactions are noted, and secondary alteration products, which influence the nuclide release from the WPA, are identified.

Although the test configuration is conceptually simple, it is complex from the point of view of the waste form reactions that are occurring. This complexity is due, in part, to the fact that it is not possible to completely control some of the potentially important experimental factors. For example, the details of the interfacial contact (e.g., contact area, flow patterns, droplet residence times on horizontal surfaces, and intermittent exposure of part of the WPA surface to wetting followed by exposure to humid air) between the waste and the injected water cannot be 
controlled precisely. It is not surprising, therefore, that s.ch experimental factors could give rise to significantly different results in replicated tests (see Results section).

The test procedure incorporates batch and continuous cesting. In the batch mode, tests are terminated at periodic time intervals. The test apparatus is disassemiled, and analyses of both the solution and components are performed. In the continuous mode, the WPA (including liquid associated with the assemblage) is transferred to a new test vessel at 6.5 to 26-week intervals, and the test is continued. Analyses are done on the solution in the old vessel. With the continuous-testing mode, replication of solution analysis can be achieved. In addition, visual observation of the test components is possible at the interim points at which the WPA is transferred to a new test vessel, and yet the test can continue for an unspecified number of test periods or until information most useful to reaction evaluation is obtained.

\section{RESULTS}

Glass

The Unsaturated Test has been applied to glass in both a standard mode $(0.075 \mathrm{~mL}$ of EJ-13 water injected every 3.5 days with a glass surface area of $\sim 13.5 \mathrm{~cm}^{2}$, presensitized $304 \mathrm{~L}$ stainless steel) and as modified to study the effects of varying the volume of water contacting the waste, the interval between water injection periods, the ratio of surface area (as-cut or cast) to water volume, and the condition of the stainless steel in contact with the glass. The conditions used in the various experiments and the status of the experiments are shown in Table I. Details of these 
first sampling period ( 6.5 weeks), extensive reaction between the metal, glass, and groundwater had occurred resulting in the formation of $\mathrm{Fe}, \mathrm{Cr}$, $\mathrm{Mn}$, and $\mathrm{Ni}$ silicates and iron oxide-hydroxide reaction products ${ }^{7}$ (Fig. 4).

In test 7 the $304 \mathrm{~L}$ steel contajned $0.017 \mathrm{wt} \%$ carbon, and the extent of sensitization was less than in test 1 . The effect of the lesser degree of sensitization is quite evident from the SEM photomicrographs in that only localized reaction of the metal and glass was observed, and the elemental release was less than that measured in test 1 .

The most extensive glass reaction was found in test 5 (Fig. 2). The larger elemental release is accompanied by a significant change in the appearance of the reacted glass surface. In all the batch samples examined, there was evidence that layers of reacted glass had spalled from the WPA during the test period and had been included with the analysis of the test solution. As shown in Fig. 5 bare glass is exposed as a result of surface layer exfoliation in regions of the surface that were not in contact with metal. These areas are partially covered with a precipitated clay, possibly smectite. Small regions where such exfoliation, followed by precipitation have occurred were observed on the long-term samples in most of the tests. They are, however, much more extensive in test 5 than in the other tests. While a definitive explanation of the exfoliation/ reprecipitation process is not available, it is possible that the reduced amount of water injected in test 5 created conditions which accelerate the process.

The elemental releases from ATM-10 glass (test 2) are shown in Fig. 6. The striking feature in the ATM-10 tests was that despite a pretreatment of the metal retainer as was done in test 1 for 165 glass, no evidence of 
strong reaction between the metal and glass is observed. Further analysis of the reacted components from test 2 may be required to completely address the apparent lack of glass/metal reaction in test 2 .

$\mathrm{UO}_{2}$

The experiments with $\mathrm{UO}_{2}$ were performed using three different pellet configurations and two different injection rates. $\mathrm{UO}_{2}$ pellets were used in the test with a measured uranium assay of $88.20 \pm 0.01 \mathrm{wt} \% \mathrm{U}$. The oxygen/metal ratio was determined by ignition at $850^{\circ} \mathrm{C}$ to be $2.000=0.002$. The concentrations of impurities in the $\mathrm{UO}_{2}$ were determined by spark source mass spectrometry are listed in Table III.

The experimental configurations were chosen to vary the surface area of $\mathrm{UO}_{2}$ available for reaction and included (tests 1 and 2) 11 as-cut slices $1.75 \mathrm{~mm}$ thick, (tests 3 and 4$) \mathrm{ca} .19 \mathrm{gm}$ of crushed $\mathrm{UO}_{2}(-60+80$ mesh) contained between two as-cut $\mathrm{UO}_{2}$ slices, and (tests 5 and 6) 3 as-formed pellets. The $\mathrm{UO}_{2}$ was contained in a tightly fitting zircaloy sleeve and supported on a PFA Tef1onTM stand to keep the WPA from contacting water that had collected in the bottom of the vessel. Each configuration was run in duplicate using the standard injection volume and rate, and the three pellet configuration was also run using a reduced injection volume of $0.0375 \mathrm{~mL}$ and an injection interval of 7 days instead of 3.5 days (tests 7 and 8$) .8$

The release of $U$ from the WPA is presented in Fig. 7. These values represent the total $U$ as measured in the acid strip of the test vessel and TefionTM stand. They include all of the uranium released from the $\mathrm{UO}_{2}$, except for that which reprecipitated on the $\mathrm{UO}_{2}$ or zircaioy assembly. The 
$U$ in solution was also measured in some of the long duration experiments by taking an unacidified aliquot. From these measurements, it was determined that the $U$ concentration averaged $2.3 \pm 1.1 \mathrm{ppm}$ which represents $\sim 5 \%$ of the total uranium released.

Several noints of interest are evident in Fig. 7 . These include the following:

- In all tests a rapid increase in the amount of $U$ released was observed between about 1-2 years of exposure to the test conditions. Approximately $65 \%$ of the total $\mathrm{U}$ release that was observed after 4.5 years occurred during this period of rapid release. This release appears to be correlated with significant etching along grain boundaries and dislodging of surface grains.

- After the rapid release period, the release rate returns to a relatively small and constant value. At this stage the formation of uranyl silicates have been observed on the surface.

- Although the general release trends are similar, large differences have been observed in replicate tests. This indicates that experimental factors such as water flow patterns are important, and may predominate over varied $\mathrm{UO}_{2}$ surface areas and drip rates as used in the tests.

One experiment from each duplicate series has been terminated and the reacted $\mathrm{UO}_{2}$ has been examined to assess the nature of reaction. The examination of the components has included visual observations made throughout the experiment, and analyses of reaction products using scanning electron microscopy and associated energy dispersive $x$-ray spectroscopy (SEM/EDS), and X-ray diffraction (XRD). Visual observation indicated that, 
for all experiments, some reaction is apparent on the top surface of the $\mathrm{UO}_{2}$ after $\sim 20$ weeks. The top surfaces become covered with yellow and white reaction products, forming patterns that correspond with water contact. The bottom surfaces of the $\mathrm{UO}_{2}$ showed more variable coverage of reaction products than the top surface, but the coverage was always far less than noted on the top surface. In some experiments the Teflon TM stand also took on a distinctively yellow color.

The reaction products as identified by XRD and SEM/EDS are listed in Table IV and consist of uranophane, which appears as a mat of fine needlelike material that is white in color which covers and is intermixed with yellow crystals or a yellow mat. The yellow crystals are comprised of many parallel plates and have been identified as schoepite, dehydrated schoepite, becquerelite, and possibly compreignacitè. The yellow mat is boltwoodite. A small amount of soddyite and sklodowskite was also identified. The paragenetic sequence observed is similar to that found in oxidized weathering horizons of uranium deposits. ${ }^{9}$ The $\mathrm{UO}_{2}$ is initially a)tered to uranyl oxide hydrates (dehydrated schoepite, schoepite, compreignacite, and becquerelite), followed closely by the precipitation of soddyite and finally the observed formation of uranyl silicates (uranophane, boltwoodite, and sklodowskite) in samples terminated after 3.5 years. The only reaction products observed on the bottom surfaces of the samples were schoepite, dehydrated schoepite, and soddyite.

Surprisingly, on the top surface around the outer perimeter of the surface, irregular clumps of teflon were also found intermixed with the uranium-containing phases. The teflon was identified by XRD, SEM/EDS, and by infrared spectroscopy. The teflon is not injected with the water during 
testing (the injected water has been analyzed repeatedly with no indication of increased organic carbon) and was not injected as particulate matter with the water. Its method of formation and effect on the reaction process are still under examination. Note that the TeflonTM stands were used primarily because of the inert nature of the material in leaching type tests. Additionally, very little, if any teflon is found on the bottom surfaces of the $\mathrm{UO}_{2}$ in most of the tests, and no teflon was found on the zircaloy. In addition, the bottom reaction products were only schoepite or dehydrated schoepite.

While the mechanism of the $\mathrm{UO}_{2}$ reaction as described above has not been investigated, it is clear that the oxidizing conditions present in the vessel, the small volumes of water that contact the $\mathrm{UO}_{2}$, and the cationic species present in the EJ-13 water combine to produce conditions conducive to the formation of a variety of uranyl phases. The reaction that occurs on the top surface depletes the solution in $\mathrm{Si}, \mathrm{Ca}$, and $\mathrm{K}$ such that only U-containing phases are found on the bottom surface. The reaction products accumulate according to water flow patterns, which are variable between samples. Thus, the total $U$ released also varies considerably between samples. Those experiments where the Teflon TM stands attain a yellow stain show the greatest release.

\section{CONCLUSIONS}

The Unsaturated Test Method has been applied to both glass and unirradiated $\mathrm{UO}_{2}$ as a way of studying waste form reaction under anticipated repository conditions. For $g$ lass, the most significant effect was observed when the volume of water, as controlled by water injection volume and 
interval period, was such to allow exfoliation of reacted glass to occur. The extent of reaction was also influenced to a lesser extent by the degree of sensitization of the 304L stainless steel in contact with the glass. The normalized releases that are observed are larger than the bounding values currently used in performance assessment calculations. 3 This indicates that it is probably inappropriate to assume that glass waste form reaction rates, under some of the plausible repository conditions (e.g., wet drip), are conservatively bounded by long-term leaching rates.

For $\mathrm{UO}_{2}$, the conditions used in the Unsaturated Test, e.g., oxidizing environment, low water volume in contact with the $\mathrm{UO}_{2}$, and cationic components in the water, are such that a variety of degradation phenomena and formation of uranium-containing secondary phases were observed. The formation of the secondary phases corresponded well with a marked increase in release of uranium from the $\mathrm{UO}_{2}$. The marked increase in uranium release appears to be correlated with the observation of dislodged $\mathrm{UO}_{2}$ grains due to intergranular corrosion. The cover of secondary phases was most extensive on the top surface where the concentration of $\mathrm{Si}, \mathrm{Ca}$, and $\mathrm{K}$ were periodically replenished by the dripping water. Secondary phases were also found on the bottom surface, but the coverage was sparse and the phases were mostly hydrated forms of $\mathrm{UO}_{3}$. The results from these experiments are instructive in that they demonstrate that many of the phases that are predicted to be formed based on geochemical modeling codes, 10,11 will form given the necessary reaction conditions. Also the amount and rate of reaction of $\mathrm{UO}_{2}$ with limited amounts of yater in an oxidizing environment exceeds that ohserved under conditions of complete spent fuel submersion as found in saturated leaching tests. 12 
Although replicate tests indicate that uncontrolled experimental factors have large effects, the results, for both glass aild $\mathrm{UO}_{2}$, indicate that the reaction of the vaste form may be significantly affected by the amount of water that contacts the waste form and by the conditions under which the contact occurs. While limited amounts of water may depress elemental transport from the near-field environment of the waste package, the rate of waste form degradation may actually be increased as the amourt of water decreases.

\section{ACKNOWLEDGMENTS}

Work supported by the U.S. Department of Energy, Office of Civilian Radioactive Waste Management, Yucca Mountain Project, under subcontract to Lawrence Livermore National Laboratory, SANL 910-005 and SANL 910-007. 


\section{REFERENCES}

1. Site Characterization Plan, U.S. Department of Energy, Office of Civilian Radioactive Waste Management, DOE report DOE/RW-0199 (1988).

2. W. J. O'Conne11, "Status of Integrated Performance Assessment of the Waste Package and Engineered Barrier System," in Proc. of the Internat. Topical Mtg. on High Level Radioactive Waste Mariagement, Las Vegas, NV, April 8-12, 1990.

3. M. J. Apted and D. W. Engel, "Mass-Transfer Analysis of Waste Packages Containing Defense Waste Processing Facility Glass as a Waste Form, " in Proc. of the Internat. Topical Mtg. on High Level Radioactive Waste Management, Las Vegas, NV, Apri1 8-12, 1990.

4. J. K. Bates and T. J. Gerding, "NNWSI Phase II Materials Interaction Test Procedure and Pre? iminary Kesults," Argonne National Laboratory report ANL-84-81 (1984).

5. J. K. Bates and T. J. Gerding, "One-Year Results of the NNWSI Unsaturated Test Procedure: SRL 165 Glass Application," Argonne National Laboratory report ANL-85-41 (1986).

6. J. K. Bates, T. J. Gerding, T. A. Abrajano, Jr., and W. L. Ebert, "NNWSI Waste Form Testing at Argonne National Laboratory, January-June 1986 Semiannual Report, "Lawrence Livermore National Laboratory report UCRL-15801-86-1 (1987).

7. J. K. Bates and T. J. Gerding, "Application of the NwWSI Unsaturated Test Method to Actinide Doped SRL 165 Type Glass," Argonne National Laboratory report ANL-89/24 (1990).

8. D. J. Wronkiewicz, J. K. Bates, T. J. Gerding, E. Veleckis, and B. S. Tani, "Leaching Patterns and Alteration Phase Production by Unsaturated Testing of $\mathrm{UO}_{2}, "$ Argonne National Laboratory report (in preparation).

9. A. C. Fronde1, "Mineral Composition of Gummite," The American Mineralogist $\underline{41}, 539-568$ (1956).

10. C. J. Bruton and H. F. Shaw, "Geochemical Simulation of Reaction Between Spent Fuel Waste Form and $\mathrm{J}-13$ Water at $25^{\circ} \mathrm{C}$ and $90^{\circ} \mathrm{C}, "$ in Scientific Basis for Nuclear Waste Management XI, Voi. 112, M. J. Apted and R. E. Westerman, eds., Materials Research Society, Pittsburgh, PA, p. 485 (1987).

11. C. N. Wilson and C. J. Bruton, "Studies of Spent Fuel Dissolution Behavior under Yucca Mountain Repository Conditions," presented at the American Ceramic Society meeting, Indianapolis, IN, April 26, 1989. 
12. C. i. Wilson, "Summary of Results from the Series 2 and Series 3 NNWSI Bare Fuel Dissolution Tests," in Scientific Basis for Nuclear waste Management XI, Vol. 112, $M$. J. Apted and R. E. Westerman, eds., Materials Research Society, Pittsburgh, PA, p. 473 (1987). 
Table I. Description, Purpose, and Stutus of Glass Related Unsaturated Tests

\begin{tabular}{|c|c|c|c|}
\hline Test No. & Description & Purpose & Status \\
\hline 1 & $\begin{array}{l}\text { Regular-sized SRL } 165 \text { glass waste } \\
\text { forms in presensitized } 0.022 \text { wt } x \\
\text { corbon as holders, } 0.076 \mathrm{~mL} \text { and } \\
\text { EJ-13/3.5 days, continuous and } \\
\text { and bateh experiments. }\end{array}$ & $\begin{array}{l}\text { To moasure glasa reaction and } \\
\text { radionuclide release under } \\
\text { stendard conditions, SRL } 165 \\
\text { type glass doped with NP, PU, } \\
\text { and Am. }\end{array}$ & $\begin{array}{l}\text { Initiated } 2 / 3 / 86 \text {. Batch } \\
\text { oxporiments completed } 2 / 2 / 87 \text {. } \\
\text { Continuous oxporiments in } \\
\text { progress. }\end{array}$ \\
\hline 2 & $\begin{array}{l}\text { Regular-sized ATM-10 glose wasto } \\
\text { forms in presensitized } \sigma .022 \text { wt } x \\
\text { carbon se holders, } 0.076 \mathrm{~mL} \text { and } \\
\text { EJ-13/3.5 days, continuous and } \\
\text { batch exporiments. }\end{array}$ & $\begin{array}{l}\text { To messure glass reaction and } \\
\text { radionucl ide release under } \\
\text { standerd conditions, ATM-10 } \\
\text { glass. }\end{array}$ & $\begin{array}{l}\text { Initiated } 7 / 5 / 87 \text {. Batch } \\
\text { experiments comploted. } \\
\text { Continuous oxperiments in } \\
\text { progress. }\end{array}$ \\
\hline 3 & $\begin{array}{l}\text { Regulsr-sized SRL } 166 \text { glase wasto } \\
\text { form, no ss holder, } 6.676 \mathrm{~mL} J-13 / \\
3.6 \text { days, continuous and batch } \\
\text { oxperiments. }\end{array}$ & $\begin{array}{l}\text { To study the relense from giass } \\
\text { only. }\end{array}$ & $\begin{array}{l}\text { Initiated } 2 / 20 / 84 \text {. Betch } \\
\text { experiments completed } 2 / 18 / 85 \text {. } \\
\text { Continuous oxporiments in } \\
\text { progress. }\end{array}$ \\
\hline 4 & $\begin{array}{l}\text { Half-sized SRL } 166 \text { glase waste } \\
\text { form, es holder, } 6.076 \mathrm{~mL} \text { and } \\
\text { EJ-13/3.6 days, continuous and } \\
\text { batch experiments. }\end{array}$ & $\begin{array}{l}\text { To study the effect of changing } \\
\text { the waste form surface aroa by } \\
\text { reducing the as-cast surtace } \\
\text { ore by half. }\end{array}$ & $\begin{array}{l}\text { Initiated 12/6/84. Batch } \\
\text { experiments ccmploted } 12 / 6 / 85 \text {. } \\
\text { Continuous oxporiments in } \\
\text { progress. }\end{array}$ \\
\hline 5 & $\begin{array}{l}\text { Half-sized SRL } 165 \text { glase waste } \\
\text { form, as holder, } 6.0376 \mathrm{~mL} \text { and } \\
\text { EJ-13/3.6 deys, continuous and } \\
\text { batch experiments. }\end{array}$ & $\begin{array}{l}\text { To study the effect of reducing } \\
\text { the volume of water added per } \\
\text { inject period with the as-cest } \\
\text { eurface area reduced by half. }\end{array}$ & $\begin{array}{l}\text { Initiated } 2 / 18 / 85 \text {. Batch } \\
\text { exper imonts completed } 2 / 17 / 86 \text {. } \\
\text { Continuous oxperiments in } \\
\text { progress. }\end{array}$ \\
\hline 6 & $\begin{array}{l}\text { Reguler-eized SRL } 165 \text { glase waste } \\
\text { form, se holder, } 6.676 \mathrm{~mL} \text { and } \\
\text { EJ-13/I4 days, continuous and } \\
\text { botch experiments. }\end{array}$ & $\begin{array}{l}\text { To study the offect of } \\
\text { lengthening the time interval } \\
\text { between water additions. }\end{array}$ & $\begin{array}{l}\text { Initiated } 6 / 16 / 85 \text {. Batch } \\
\text { exporimonts comploted through } \\
\text { two yoars, Continuous and batch } \\
\text { exporiments in progress. }\end{array}$ \\
\hline 7 & 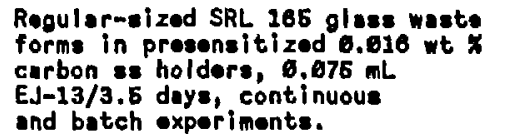 & $\begin{array}{l}\text { To etudy the offect of } \\
\text { presensitizing the es waste form } \\
\text { holder using low carbon ss. }\end{array}$ & $\begin{array}{l}\text { Initiated } 2 / 27 / 86 \text {. Batch } \\
\text { experiments completed through } \\
\text { two years. Continuous and } \\
\text { bstch exporiments in progress. }\end{array}$ \\
\hline
\end{tabular}


Table II. Composition of Glasses Used in the Unsaturated Tests

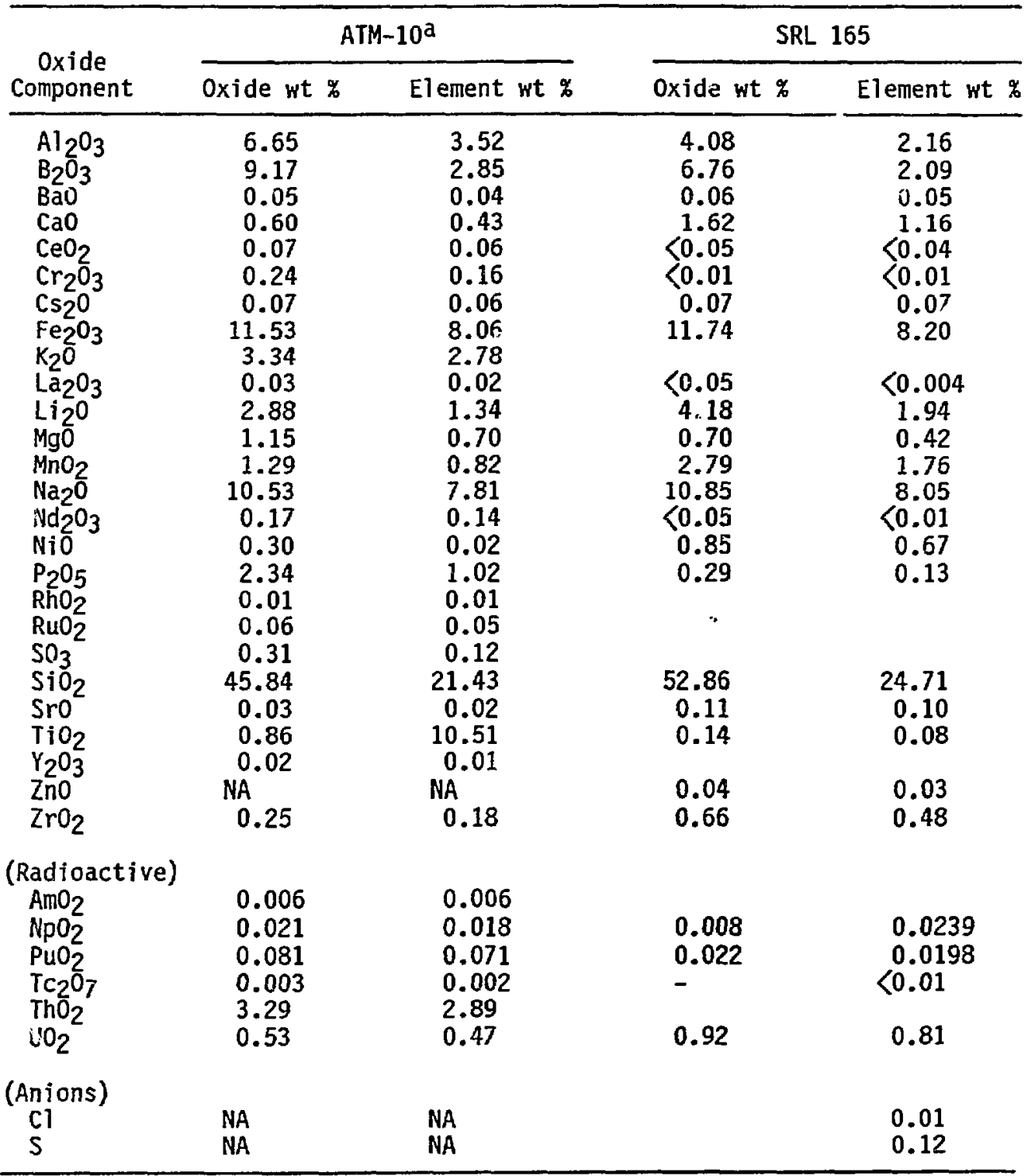

aComposition reported by the MCC. The glass was remelted and cast prior to use in the Unsaturated Test.

NA - Not analyzed. 


\begin{tabular}{|c|c|c|c|c|c|}
\hline A1 & 4 & $\mathrm{Cu}$ & 3 & $S$ & 0.9 \\
\hline As & 0.5 & $\mathbf{F}$ & 0.1 & Sc & $<0.06$ \\
\hline$B$ & 1 & $\mathrm{Fe}$ & 20 & Si & $<2$ \\
\hline $\mathrm{Ba}$ & 0.4 & 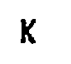 & 0.3 & Th & 15 \\
\hline $\mathrm{Bi}$ & $<0.2$ & $\mathrm{Mg}$ & $<0.7$ & $T i$ & 0.4 \\
\hline $\mathrm{Ca}$ & 2 & $M n$ & 0.3 & $v$ & 0.3 \\
\hline $\mathrm{Cl}$ & 0.2 & $\mathrm{Na}$ & 0.9 & $Y$ & 0.4 \\
\hline $\mathrm{Co}$ & 0.2 & $\mathrm{Ni}$ & 2 & $\mathrm{Zn}$ & 0.3 \\
\hline $\mathrm{Cr}$ & 0.7 & $P$ & 0.8 & $\mathrm{Zr}$ & $<0.5$ \\
\hline
\end{tabular}

*Spark source mass spectrometric analysis. 
Table IV. Phases Identified by XRD and EDS

\begin{tabular}{ll}
\hline \multicolumn{1}{c}{ Phase } & \multicolumn{1}{c}{ Formula } \\
\hline Schoepite & $\mathrm{UO}_{3} \cdot 2 \mathrm{H}_{2} \mathrm{O}$ \\
Dehydrated Schoepite & $\mathrm{UO}_{3} \cdot 0.8 \mathrm{H}_{2} \mathrm{O}$ \\
Compreignacite & $\mathrm{K}_{2} \mathrm{U}_{6} \mathrm{O}_{19} \cdot 11 \mathrm{H}_{2} \mathrm{O}$ \\
Uranophane & $\mathrm{Ca}\left(\mathrm{UO}_{2}\right)_{2}\left(\mathrm{SiO}_{3}\right)_{2}(\mathrm{OH})_{2} \cdot 5 \mathrm{H}_{2} \mathrm{O}$ \\
Boltwoodite & $\mathrm{K}\left(\mathrm{H}_{3} \mathrm{O}\right)_{\mathrm{UO}_{2}}\left(\mathrm{SiO}_{4}\right) \cdot \mathrm{nH}_{2} \mathrm{O}$ \\
Sklodowskite & $\mathrm{Mg}_{\left(\mathrm{UO}_{2}\right)_{2}\left(\mathrm{SiO}_{3} \mathrm{OH}\right)_{2} \cdot 5 \mathrm{H}_{2} \mathrm{O}}$ \\
Becquerelite & $\mathrm{CaU} \mathrm{O}_{19} \cdot 1 \mathrm{OH}_{2} \mathrm{O}$ \\
Soddyite & $\mathrm{U}_{5} \mathrm{Si}_{2} \mathrm{O}_{19} \cdot 6 \mathrm{H}_{2} \mathrm{O}$ \\
Teflon & $\mathrm{Not} \mathrm{Determined}$
\end{tabular}




\section{LIST OF FIGURES}

Figure 1. A Schematic Diagram of the Unsaturated Test Apparatus Used with $\mathrm{UO}_{2}$.

Figure 2. Normalized Release of $L i, B$, and $U$ in Glass Unsaturated Tests (165 G1ass).

Figure 3. SEM Photomicrograph of a Reacted Surface of Glass from Test 3. Magnification equals $100 \mathrm{X}$, the marker is $100 \mu \mathrm{m}$.

Figure 4. SEM Photomicrograph of Metal-Rich Reaction Products tilat Form in Test 1. Magnification $150 \mathrm{X}$, the marker is $100 \mu \mathrm{m}$.

Figure 5. SEM Photomicrograph of a Bare Section of Glass from Test 4 that has Undergone Exfoliation of the Reacted Layer, Followed by Reprecipitation.

Figure 6. Normalized Release of Li, B, and $U$ in Glass Unsaturated Tests (ATM-10 Glass). The tests were run in triplicate and are identified as $2 a, 2 b$, and $2 c$.

Figure 7. Release of Uranium in the $\mathrm{UO}_{2}$ Unsaturated Test. 


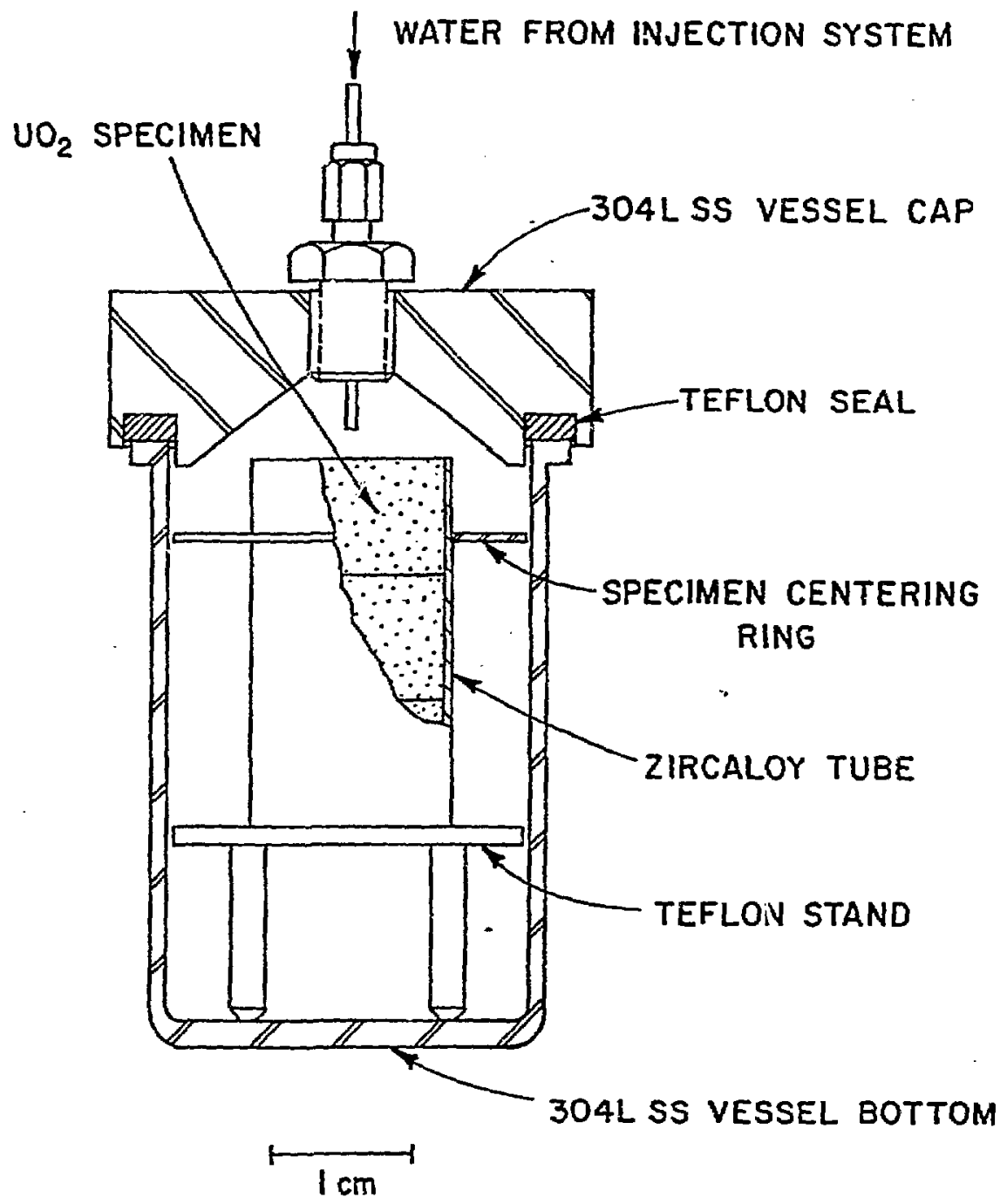

Figure 1. A Schematic Diagram of the Unsaturated Test Apparatus Used with $\mathrm{UO}_{2}$. 

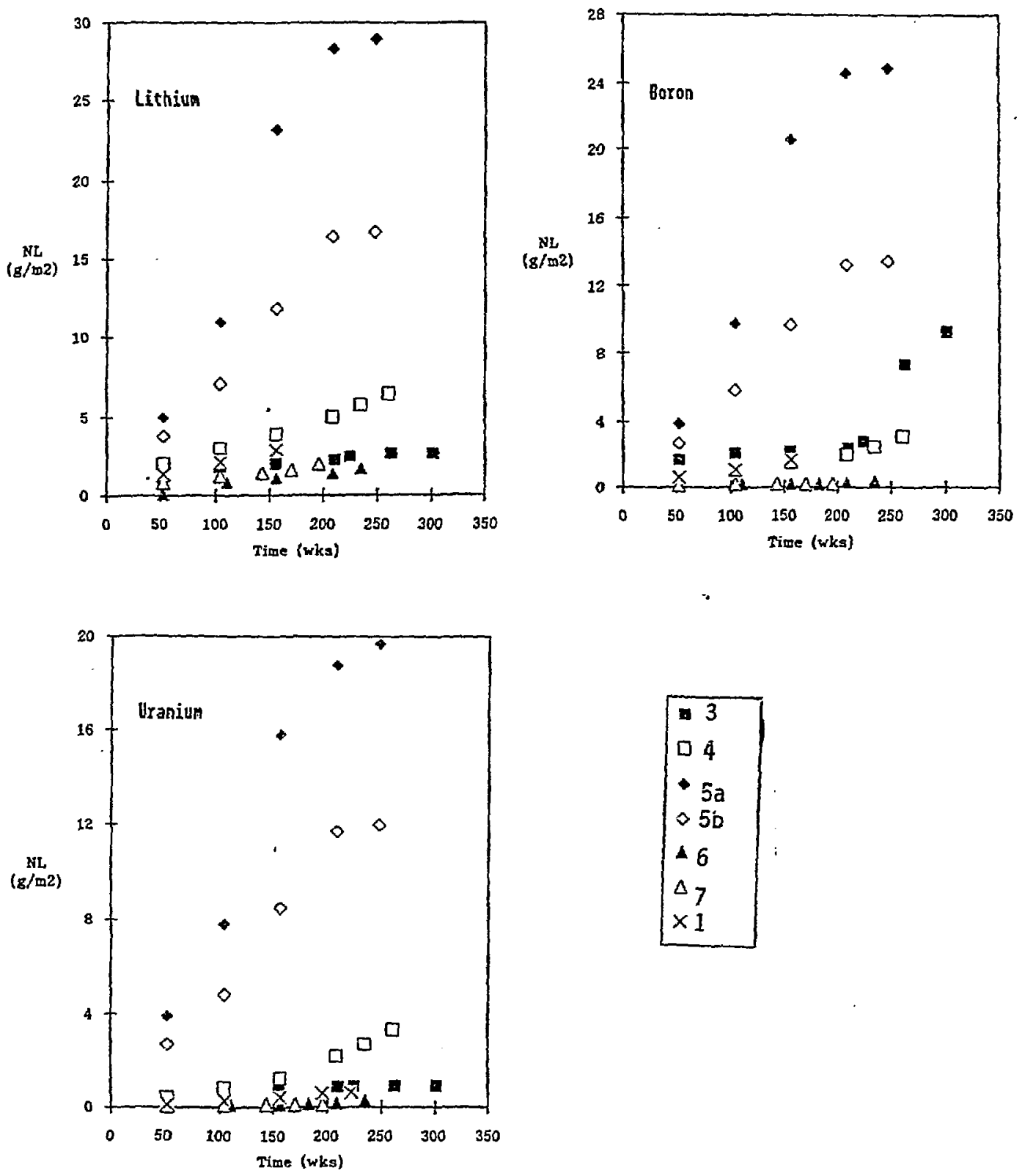

Figure 2. Normalized Release of $\mathrm{Li}, \mathrm{B}$, and $U$ in Glass Unsaturated Tests (165 Giass). 


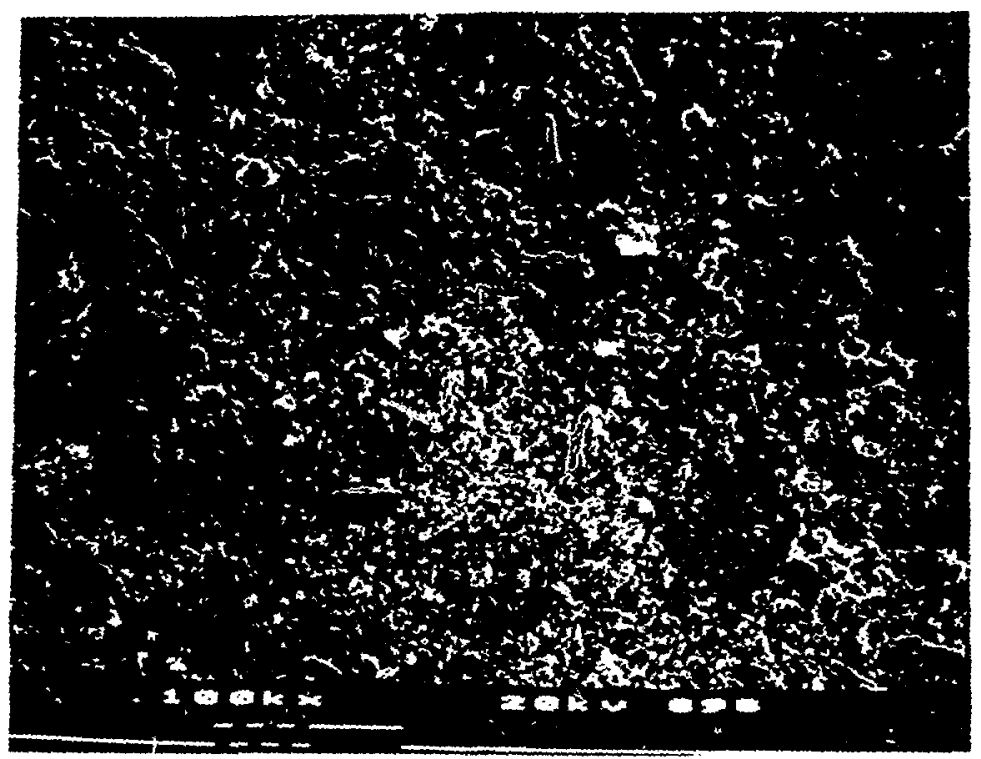

Figure 3. SEM Photomicrograph of a Reacted Surface of Glass from Test 3. Magnification equals $100 \mathrm{X}$, the marker is $100 \mu \mathrm{m}$.

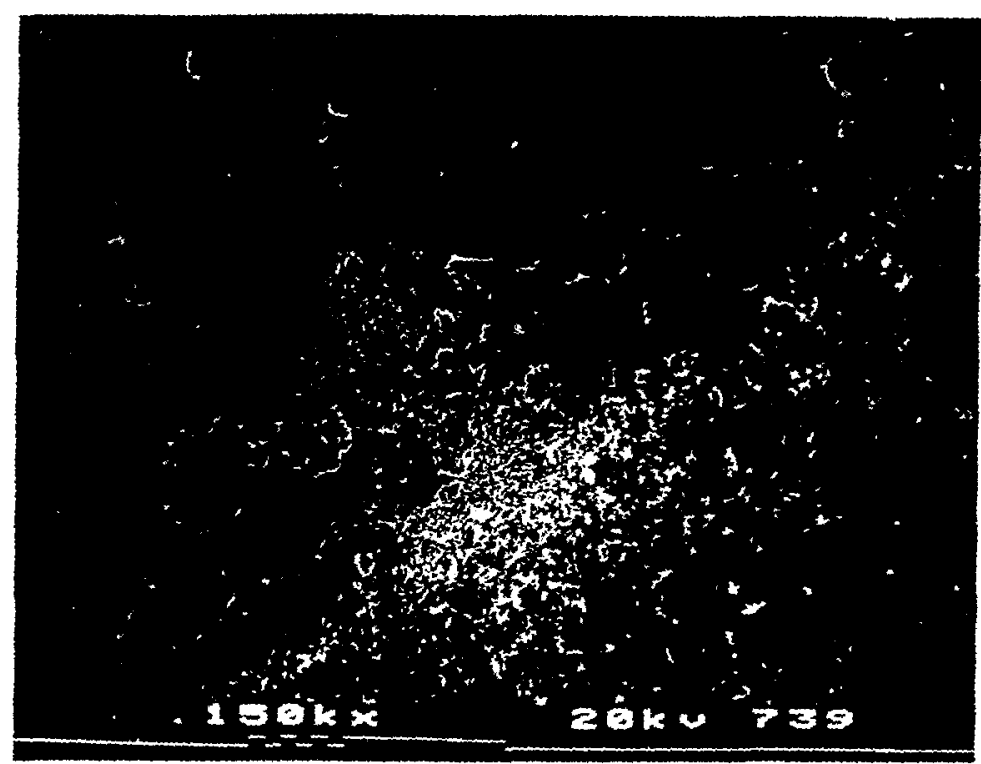

Figure 4. SEM Photomicrograph of Metal-Rich Reaction Products that Form in Test 1. Magnification $150 \mathrm{x}$, the marker is $100 \mu \mathrm{m}$. 


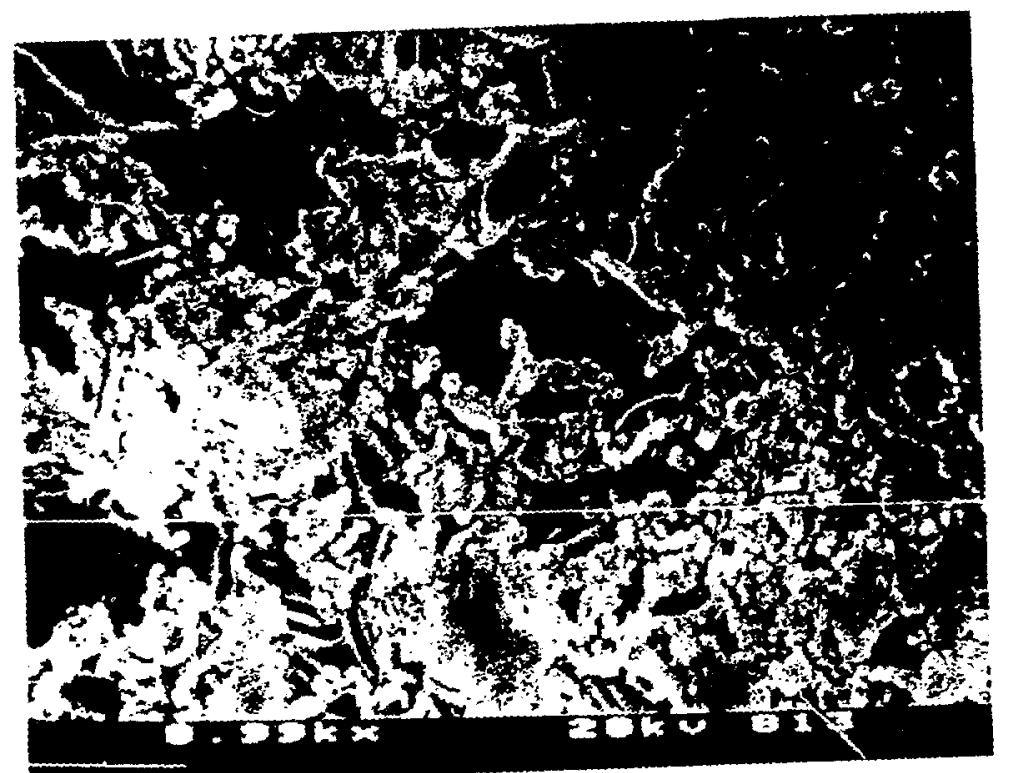

Figure 5. SEM Photomicrograph of a Bare Section of Glass from Test 4 that has Undergone Exfoliation of the Reacted Layer, Followed by Reprecipitation. 

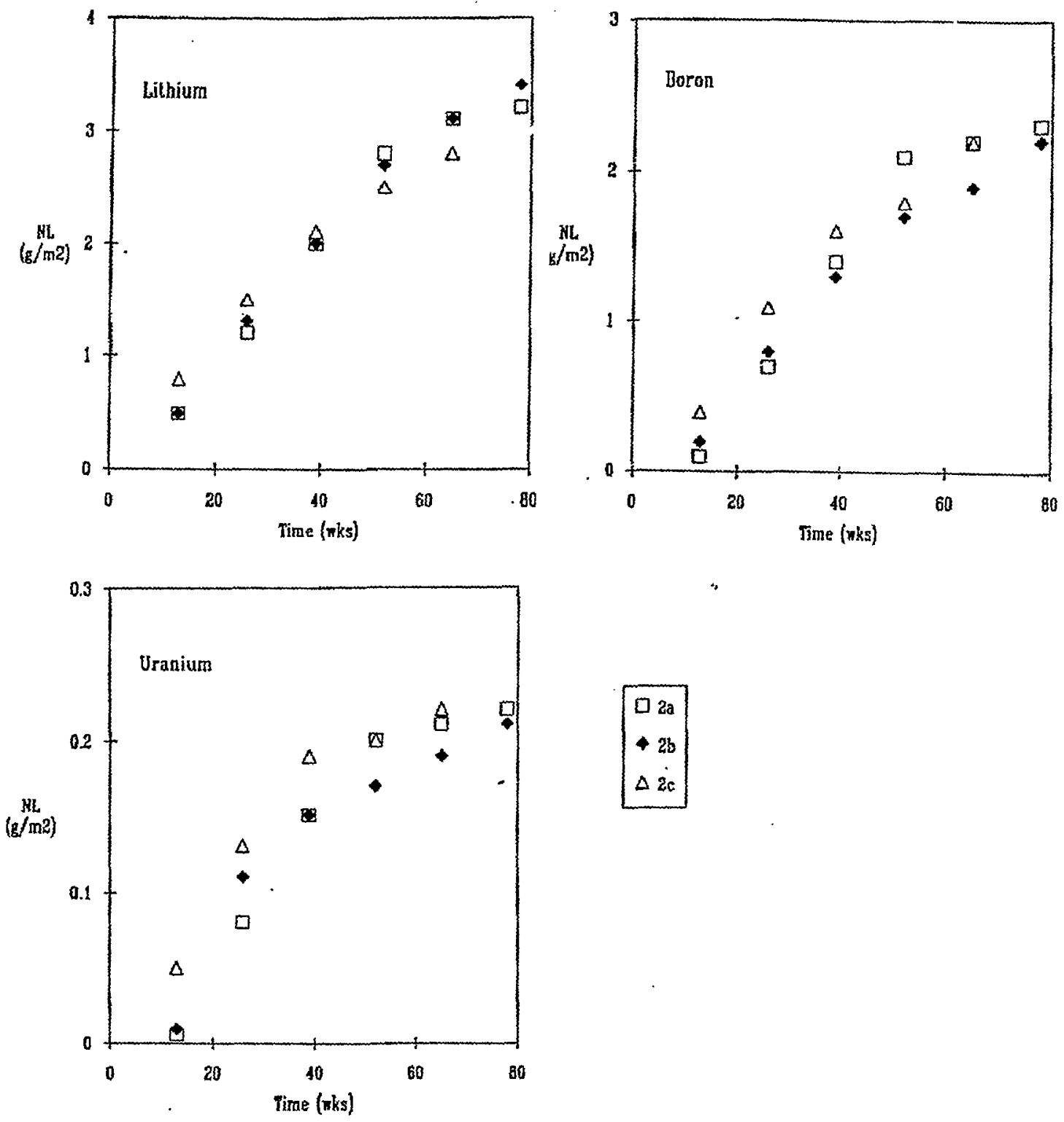

$$
\begin{gathered}
02 a \\
42 b \\
\Delta 2 c
\end{gathered}
$$

Figure 6. Normalized Release of Li, B, and $U$ in Glass Unsaturated Tests (ATM-10 GTass). The tests were run in triplicate and are identified as $2 a, 2 b$, and $2 c$. 

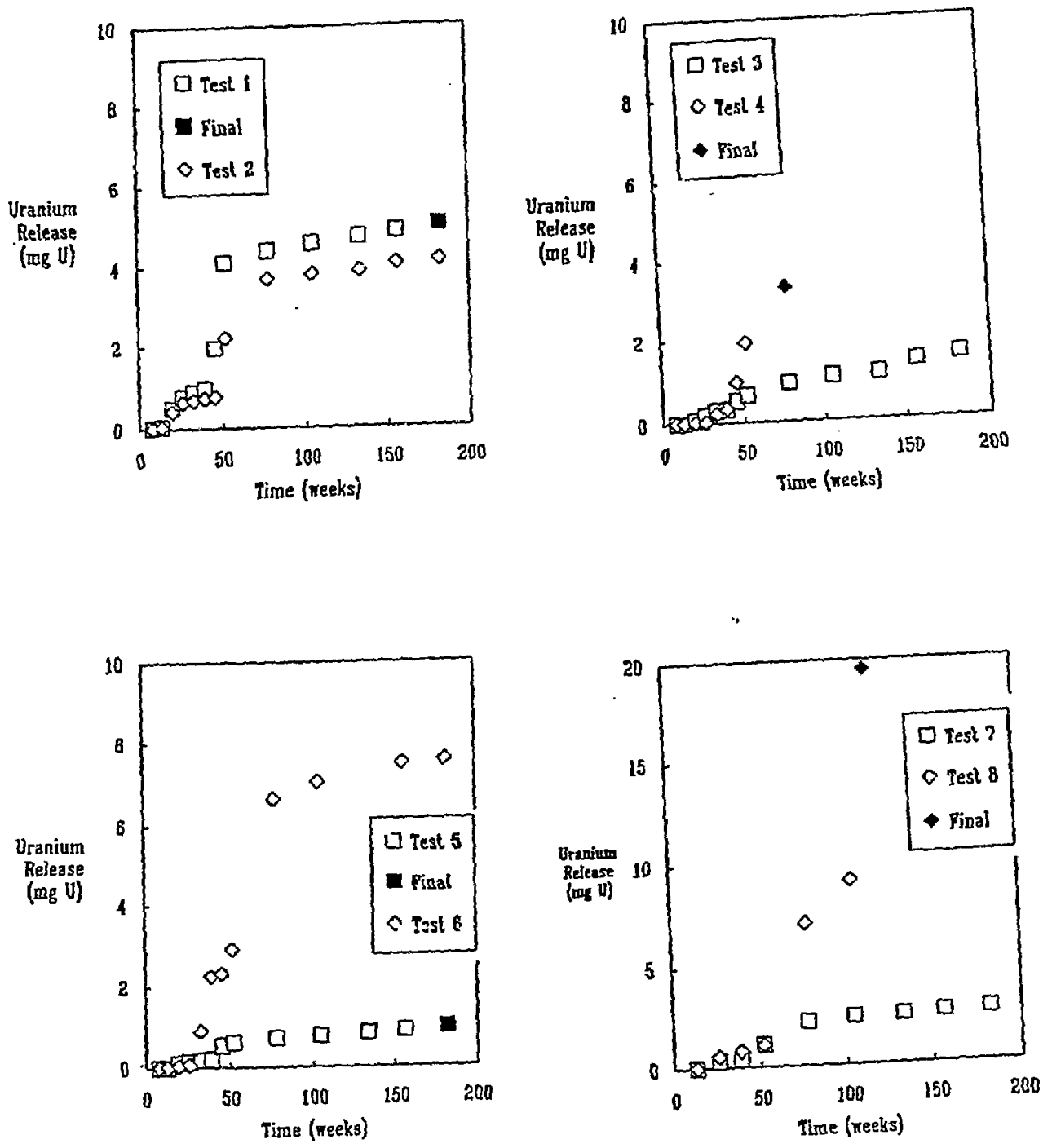

Figure 7. Release of Uranium in the $\mathrm{UO}_{2}$ Unsaturated Test. 